\title{
Trichodina colisae (Ciliophora: Trichodinidae): new parasite records for two freshwater fish species farmed in Brazil
}

\author{
Trichodina colisae (Ciliophora: Trichodinidae): novo registro de parasito para \\ duas espécies de peixes de água doce cultivadas no Brasil
}

\begin{abstract}
Gabriela Tomas Jerônimo ${ }^{1}$; Natália da Costa Marchiori ${ }^{1}$; Santiago Benites de Pádua ${ }^{2}$; José Dias Neto ${ }^{2}$; Fabiana Pilarski²; Márcia Mayumi Ishikawa ${ }^{3}$; Maurício Laterça Martins ${ }^{1 *}$

${ }^{1}$ Laboratório AQUOS - Sanidade de Organismos Aquáticos, Departamento de Aquicultura, Centro de Ciências Agrárias - CCA, Universidade Federal de Santa Catarina - UFSC, Florianópolis, SC, Brasil

${ }^{2}$ Laboratório de Patologia de Organismos Aquáticos - LAPOA, Centro de Aquicultura, Universidade Estadual Paulista - UNESP, Jaboticabal, SP, Brasil

${ }^{3}$ Embrapa Agropecuária Oeste, Empresa Brasileira de Pesquisa Agropecuária - EMBRAPA, Dourados, MS, Brasil
\end{abstract}

Received February 13, 2012

Accepted October 1, 2012

\begin{abstract}
Family Trichodinidae comprises ciliate protozoa distributed worldwide; they are considered some of the main parasitological agents infecting cultivated fish. However, the trichodinidae parasitizing important fish species cultured in Brazil are unknown, and more taxonomic studies on this group of parasites are required. This research morphologically characterizes Trichodina colisae Asmat \& Sultana, (2005) of pacu (Piaractus mesopotamicus) and patinga hybrid (P. mesopotamicus $\times$ P. brachypomus) cultivated in the central and southeast regions of the country. Fresh assemblies were made from mucus scraped from the skin, fins and gills, fixed with methanol and, subsequently, impregnated with silver nitrate and stained with Giemsa for assessment under light microscopy. This research reports not only the second occurrence of T. colisae in the world, but also its first occurrence in South America.
\end{abstract}

Keywords: Pacu, patinga hybrid, fish parasite, aquaculture health.

\section{Resumo}

Tricodinídeos são protozoários ciliados móveis com ampla distribuição mundial; são considerados um dos agentes parasitários que mais acometem peixes cultivados. No Brasil, a maioria dos tricodinídeos que parasitam importantes espécies de peixes cultivados são desconhecidos, o que requer mais estudos taxonômicos com esse grupo de parasitos. Este estudo caracteriza morfologicamente Trichodina colisae Asmat \& Sultana, 2005 de pacu (Piaractus mesopotamicus) e do híbrido patinga ( $P$. mesopotamicus $\times$ P. brachypomus) cultivados, respectivamente, no Centro-Oeste e Sudeste do Brasil. Foram feitas montagens a fresco do raspado de muco da pele, nadadeiras e brânquias, fixados com metanol e, posteriormente, impregnados com nitrato de prata e coradas com Giemsa para avaliaçáo em microscopia óptica. O presente estudo relata não só a segunda ocorrência de T. colisae no mundo, mas também a primeira ocorrência na América do Sul.

Palavras-chave: Pacu, patinga, parasito de peixe, sanidade aquícola.

\section{Introduction}

Trichodinids are ciliate protozoa widely known as ectocommensals and/or parasites of fishes. Members of the family Trichodinidae, they present complex structures on the aboral face, composing the adhesive disk (BASSON; VAN AS, 2006), which presents fast circular movements that can cause abrasive lesion on the host when at high levels of parasitism, even being able to cause mortality (KHAN, 2004). Situations like these usually occur in fish breeding, since changes in the environmental quality directly influence the occurrence of these protozoa (HOSSAIN et al., 2008).

\footnotetext{
*Corresponding author: Maurício Laterça Martins

Laboratório AQUOS - Sanidade de Organismos Aquáticos, Departamento de Aquicultura, Universidade Federal de Santa Catarina - UFSC, Rod. Admar

Gonzaga, 1346, CEP 88040-900, Florianópolis, SC, Brasil

e-mail:mlaterca@cca.ufsc.br
}

Knowledge on the fauna of trichodinidae infecting fish in Brazil is little known. So far, only the occurrence of Tripartiella pseudoplatystomae in pintado (Pseudoplatystoma corruscans) (PINTO et al., 2009) and Trichodina heterodentata in pacu (Piaractus mesopotamicus) (PÁDUA et al., 2012) were reported in Brazilian native fishes. Nevertheless, Trichodina compacta and Trichodina magna have been reported in Nile tilapia (GHIRALDELLI et al., 2006; MARTINS; GHIRALDELLI, 2008) and T. heterodentata in channel catfish (MARTINS et al., 2010); they are both exotic species farmed in Brazil.

The industrial production of native freshwater fish in Brazil is concentrated in the central and north regions, being less in the northeast, southeast and south regions of the country. Roundfish are among the species farmed in Brazil, including pacu (Piaractus 
mesopotamicus), tambaqui (Colossoma macropomum), pirapitinga (Piaractus brachypomus), and the hybrids tambacu (C. macropomum $\times$ $P$. mesopotamicus), tambatinga (C. macropomum $\times$ P. brachypomus) and patinga (P. mesopotamicus $\times$ P. brachypomus). Little information is available regarding parasite infecting these fishes in commercial production systems.

This study contributes to the description of Trichodina colisae Asmat and Sultana (2005) as a new parasite for pacu and patinga hybrid farmed in Brazil.

\section{Materials and Methods}

Pacu were captured in fish ponds in the southeast region of the country (20 $20^{\prime} 47.1^{\prime \prime} \mathrm{S}$ and $\left.48^{\circ} 11^{\prime} 27.1^{\prime \prime} \mathrm{O}\right)$ and were denominated Population A; hybrid patinga ( $P$. mesopotamicus $\times$ $P$. brachypomus) farmed in fish ponds were captured in the southeast region (22 $14^{\prime} 22.7^{\prime \prime} \mathrm{S}$ and $\left.48^{\circ} 17^{\prime} 33.4^{\prime \prime} \mathrm{O}\right)$ and denominated Population B; whereas pacu were captured in fish ponds in the central regions (22 $19^{\prime} 42.7^{\prime \prime} \mathrm{S}$ and $\left.54^{\circ} 43^{\prime} 55.2^{\prime \prime} \mathrm{O}\right)$ and were denominated Population C. Fresh assemblies from mucus scraped from the skin, fins and gills were assessed using light microscopy for the searching of trichodinidae. When positive, the slides were dried; 30\% were fixed with methanol and stained with Giemsa
(1 drop: $1 \mathrm{~mL}$ of distilled water, from 120 to 180 minutes) to highlight the nuclear apparatus. Others (70\%) were subjected to impregnation with silver nitrate $(2 \%)$ for observation of the adhesive disk (KLEIN, 1958).

The span of the denticle was measured from the blade tip to the ray tip, as described by Arthur and Lom (1984). All measures are in micrometers and follow the recommendations by Lom (1958) and Van As and Basson (1989), using photomicrographies taken with Nikon E200 ${ }^{\circledR}$ light microscope, equipped with Moticam $2300^{\circledR}$ image capture system. The measurement of the parasite was performed with the assistance of Image-Pro Plus ${ }^{\circledR}$ software. In addition, the schematic diagram of the denticles, as proposed by Van As and Basson (1989), was built through vectorization, using CorelDRAW ${ }^{\circledR}$ X5 software.

\section{Results}

In this study, medium-sized, disk format trichodinids were found on the skin, fins and gills in 100\% of pacu (Population A) and hybrid patinga (Population B) in southeastern Brazil, as well as on the skin and fins of $52 \%$ the analyzed pacu (Population C) from central region (Figure 1a-c). Measurements of taxonomic characters of the three populations are listed in Table 1. The
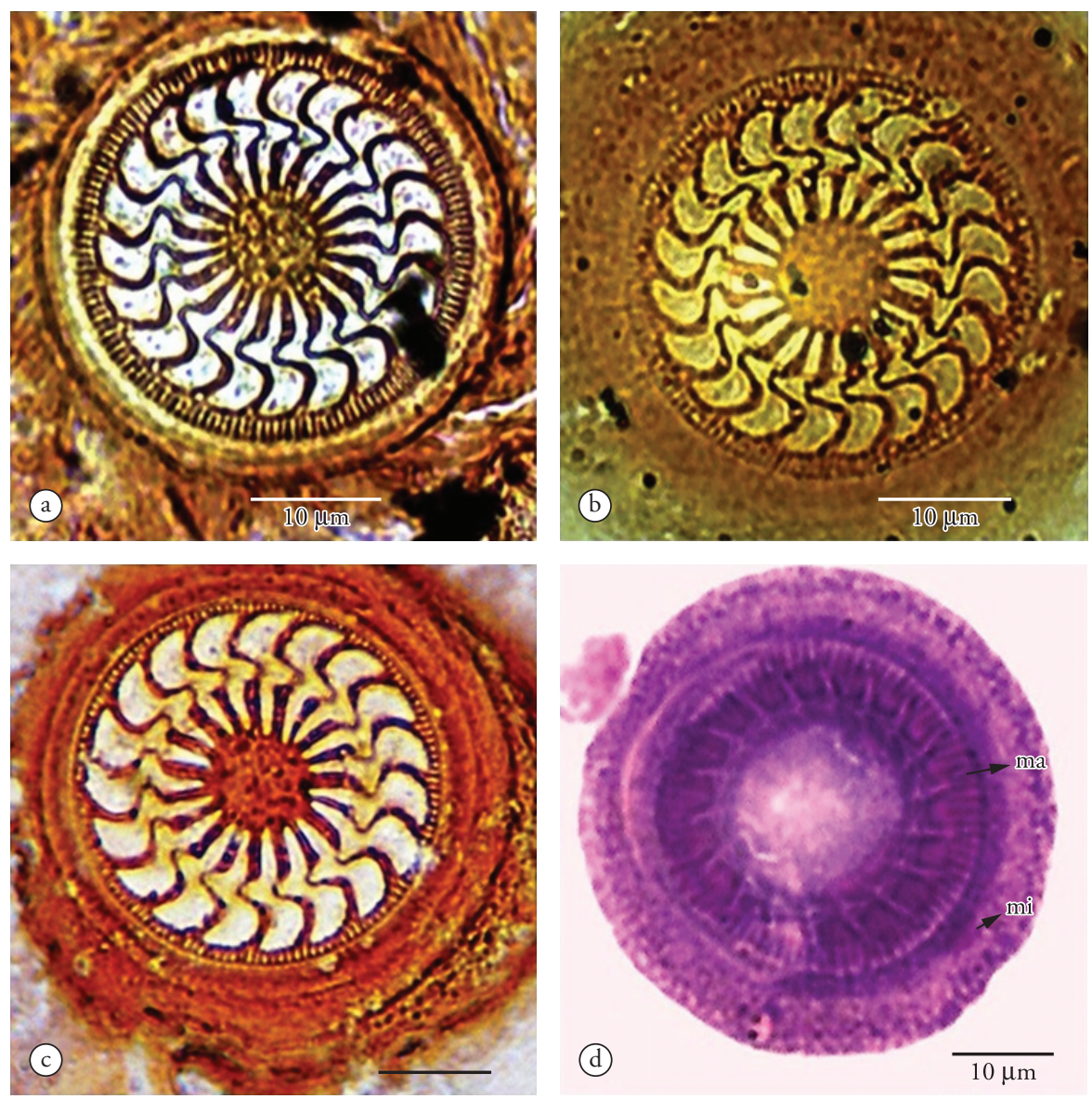

Figure 1. Klein's silver impregnated Trichodina colisae Asmat and Sultana (2005) from pacu (a) and hybrid patinga (b) in Southeastern Brazil, and pacu (c) from Central Brazil. Giemsa-stained nuclear apparatus (d) showing the horseshoe-shaped macronucleus (ma) and oval micronucleus (mi). Bar $=10 \mu \mathrm{m}$. 
measurements of Trichodinidae populations A, B and C were set based on the assessment of 30, 45 and 28 specimens, respectively.

This trichodinid presents wide blade, forming a moderately closed angle, fitting itself in the quadrant delimited by the axes $\mathrm{y}$ and $\mathrm{y}+1$. The anterior margin of the blade is convex and its apex, in most cases, surpasses the axis $y+1$. However, in some specimens, the blade apex touches the axis $y+1$ without surpassing it. The distal surface of the blade is flat, sometimes round, parallel to the membrane of the border. The point of tangency is oblong in most individuals and may present acute angle in others, it is situated slightly above or at the same height of the distal point of distal surface in populations $A$ and $B$, but below or at the same height from the distal point of distal surface in population $\mathrm{C}$. Blade apophysis is not present. The blade fitting with the central part is thin on populations $\mathrm{A}$ and $\mathrm{B}$, and robust in population $\mathrm{C}$ (Figure 2 ). No posterior projection was observed in the sample. The central part is thin, triangular, with no conical part, with an oblong tip and free from indentation below the $\mathrm{X}$ axis. In some specimens, the presence of discrete apophysis near the fitting with the ray was noticed. The ray is moderately thick, inflated, straight, and oblong-tipped, usually accompanying the $\mathrm{Y}$ axis in most individuals; some may present different lengths in the same specimen, but this difference is discreet. In population A, few individuals showed discreetly posterior-directed rays, with its proximal portion surpassing the $\mathrm{Y}$ axis. On the other hand, in population $\mathrm{B}$, in some cases, the radius is projected anteriorly, with its proximal portion surpassing the axis $y+1$. The nuclear apparatus, evidenced by the Giemsa staining, revealed the presence of horseshoe-shaped macronucleus, with oval micronucleus located in the $+y$ portion. However, the micronucleus was only detected in some specimens (Figure 1d).

Table 1. Measurements $(\mu \mathrm{m})$ of Trichodina colisae Asmat and Sultana (2005) from two cultured freshwater fish in Brazil. Population A and C have the pacu as host; population B have the hybrid patinga as host.

\begin{tabular}{|c|c|c|c|}
\hline Characters & Population A & Population B & Population C \\
\hline Local & Southeastern Brazil & Southeastern Brazil & Central Brazil \\
\hline Body $^{\mathrm{D}}$ & $35.6 \pm 2.6(31.2-41.4)$ & $40.0 \pm 3.7(32.0-46.6)$ & $41.9(34.7-51.3)$ \\
\hline Border membrane $\mathrm{W}^{\mathrm{W}}$ & $3.1 \pm 0.4(2.2-4.2)$ & $3.5 \pm 0.4(2.1-4.3)$ & - \\
\hline Adhesive disc ${ }^{\mathrm{D}}$ & $29.5 \pm 2.4(24.2-33.9)$ & $32.9 \pm 3.4(25.6-39.6)$ & $33.3(26.8-48.9)$ \\
\hline Denticular ring ${ }^{\mathrm{D}}$ & $17.7 \pm 1.8(14.5-20.6)$ & $19.7 \pm 2.6(14.8-25.2)$ & $19.7(15.0-24.4)$ \\
\hline Number of denticles & $21.1 \pm 1.4(19-24)$ & $20.9 \pm 1.6(17-25)$ & $20.5(18-23)$ \\
\hline Denticle span & $9.6 \pm 1.0(7.6-11.7)$ & $10.4 \pm 1.2(7.8-13.9)$ & $9.6(5.5-11.8)$ \\
\hline Denticle $^{\mathrm{L}}$ & $4.7 \pm 0,6(3.7-5.7)$ & $6.1 \pm 0.7(4.2-7.7)$ & $5.0(4.0-7.1)$ \\
\hline Blade $^{\mathrm{L}}$ & $4.0 \pm 0.3(3.5-4.8)$ & $3.9 \pm 0.4(3.1-4.8)$ & $4.0(3.1-5.5)$ \\
\hline Central Part ${ }^{\mathrm{W}}$ & $1.5 \pm 0.3(0.9-2.1)$ & $2.0 \pm 0.3(1.3-2.6)$ & $1.7(1.3-2.3)$ \\
\hline $\operatorname{Ray}^{\mathrm{L}}$ & $4.1 \pm 0.7(2.8-5.7)$ & $4.3 \pm 0.8(2.8-6.9)$ & $4.7(3.1-8.6)$ \\
\hline Pins per denticle & $5.7 \pm 0.8(5-8)$ & $7.0 \pm 0.8(5.0-8.0)$ & $8.3(7-10)$ \\
\hline
\end{tabular}

Ddiameter, ${ }^{{ }^{w}}$ width, length.
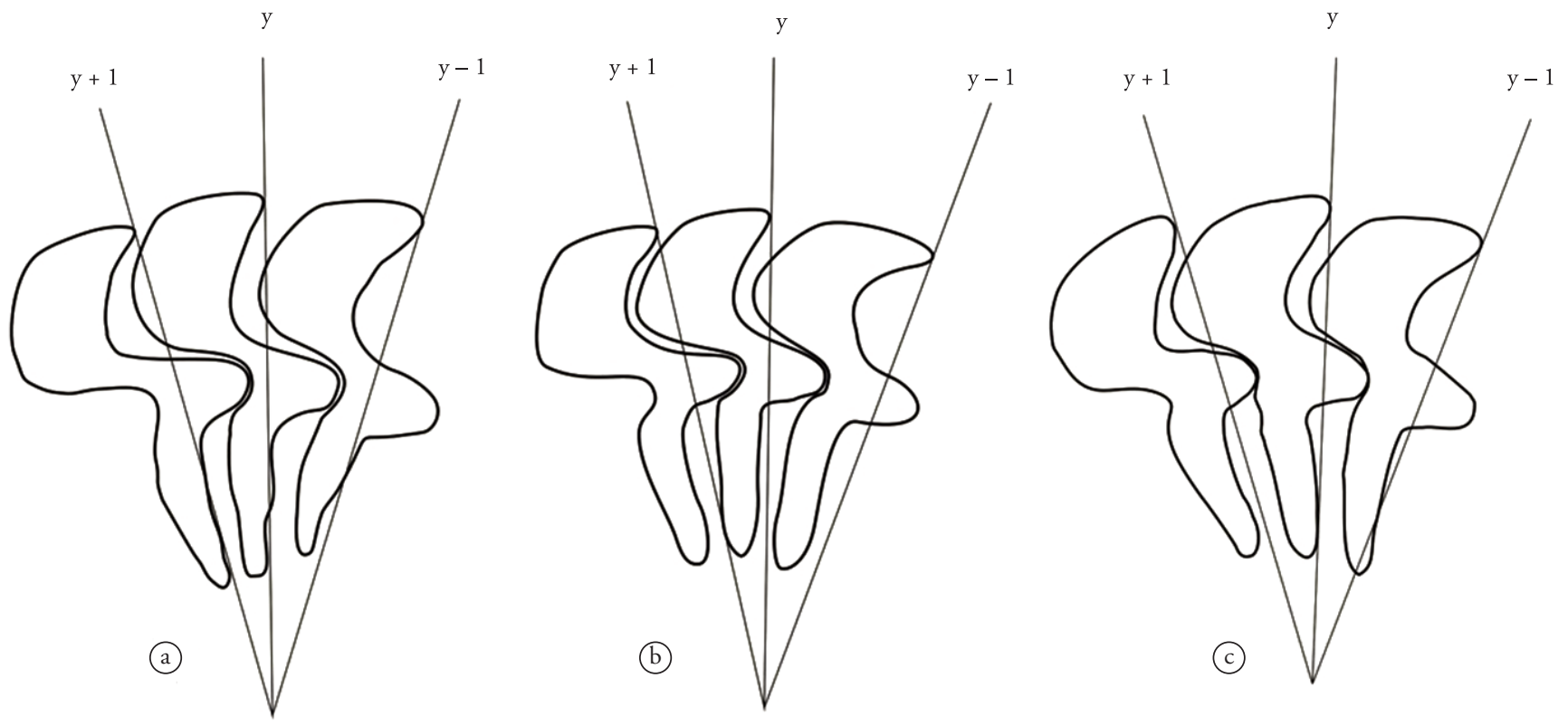

Figure 2. Schematic drawing of the denticles of Trichodina colisae Asmat and Sultana (2005) from pacu (a) and hybrid patinga (b) in Southeastern Brazil, and pacu (c) from Central Brazil. 


\section{Remarks}

From the comparison of the 11 taxonomic characters obtained in the measurements of 10 species of trichodinidae previously described in the literature (Table 2), it was possible to observe that $45.5 \%$ of the characteristics were similar to Trichodina nigra Lom (1960) in the description by Basson et al. (1983) and Trichodina pagoda Basson and Van As (1994). Trichodina erbilensis
Shwani et al. (2010) and Trichodina ngoma Van As and Basson (1992) presented 63.6\% similarity, whereas Trichodina modesta Lom (1970) and Trichodina minuta Basson et al. (1983) matched $81.8 \%$ of the measurements in this study. The trichodinids with over $90 \%$ of observed similarities were Trichodina kazubski Van As and Basson (1989) (90.9\%), Trichodina nkasa Van As and Basson (1992) (90.9\%), Trichodina matsu Basson and Van As (1994), and Trichodina colisae Asmat and Sultana (2005) (100\% both).

Tabela 2. Measurements $(\mu \mathrm{m})$ of the most similar species of Trichodina with the present material. The means are followed by standard deviation, and in parenthesis the minimum and maximum values.

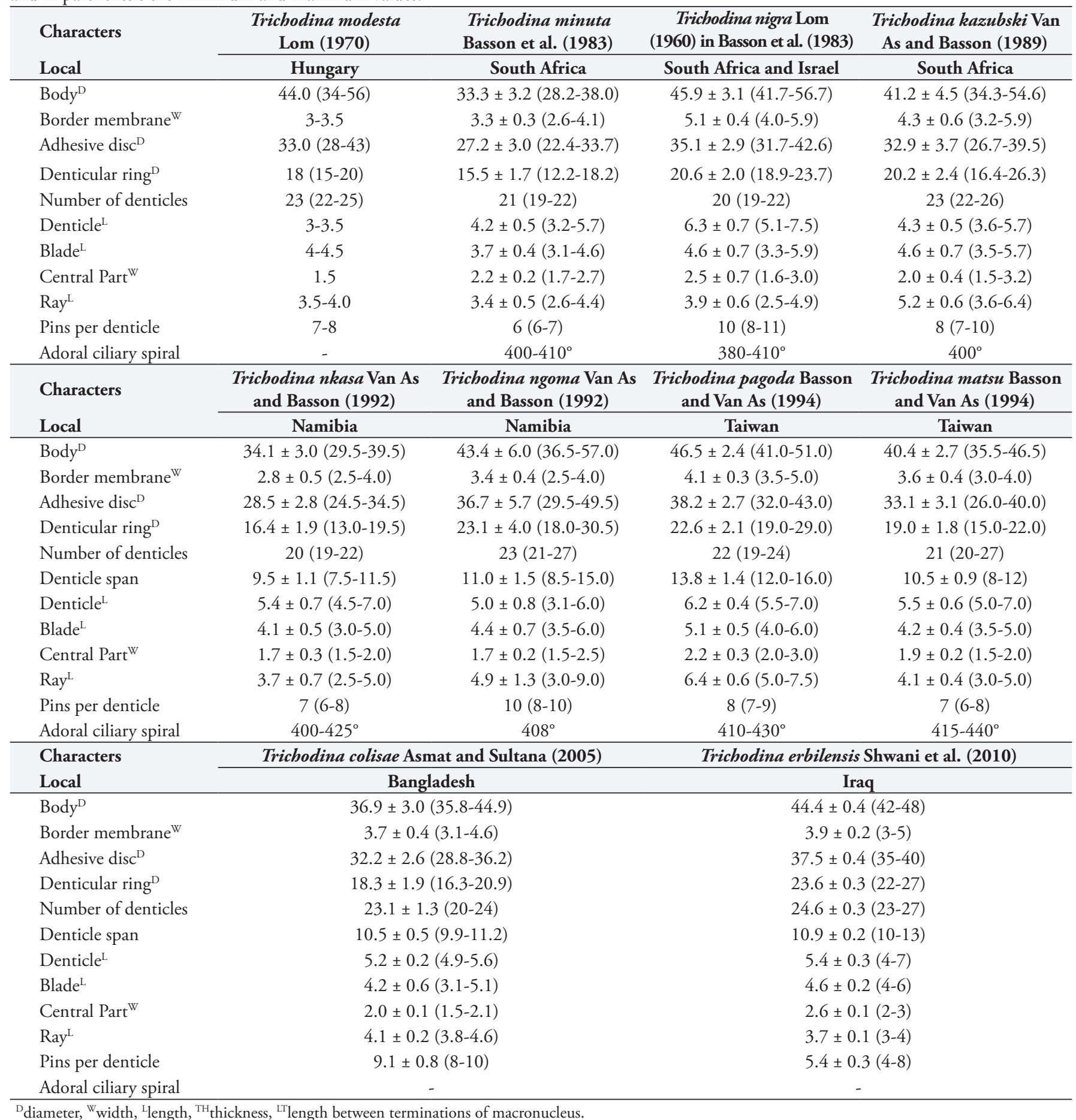

\footnotetext{
${ }^{\mathrm{D}}$ diameter, ${ }^{\mathrm{W}}$ width, ${ }^{\mathrm{L}}$ length, ${ }^{\mathrm{TH}}$ thickness, ${ }^{\mathrm{LT}}$ length between terminations of macronucleus.
} 
Trichodina pagoda (Basson and Van As, 1994) and T. erbilensis (Shwani et al., 2010) are similar to the material of this study regarding the number of denticles, pins per denticle, length of denticle, and ray length. T. ngoma (Van As and Basson, 1992) is similar concerning body measurement, border membrane, number of denticles, radial pins by denticle, denticle length, central part and ray length. On the other hand, T. minuta Basson et al. (1983) differs from the species found in this research in denticle length and ray length, which were smaller in this species. Similarly, T. nkasa (Van As and Basson, 1992) shows ray of smaller size, and this species also has a prominent apophysis in the fitting of the central part with the ray. In this research, it was possible to observe only a discrete apophysis in some specimens.

The border membrane is broad in T. kazubski (Van As and Basson, 1989), which can be confirmed in the description by Tang et al. (2007) for specimens collected from cyprinids in China. Additionally, this species differs from the others by presenting apophysis in the anterior blade margin and prominent apophysis of the ray (VAN AS; BASSON, 1989). In the central part, T. kazubski (Van As and Basson, 1989) shows discreet indentation below the $\mathrm{X}$ axis, opposite to the ray apophysis of the posterior denticle, which was not perceived in this research.

Two species of trichodinidae showed $100 \%$ of morphometric similarity with the specimens analyzed in this study, namely T. matsu (Basson and Van As, 1994) and T. colisae (Asmat and Sultana, 2005). Asmat and Sultana (2005) recognized the similarity between these species and have set some criteria to distinguish the two of them. Among these criteria, the following were observed in the sample specimens, namely: 1 - absence of indentation in the inferior part of the $\mathrm{X}$ axis of the central part of T. colisae; 2-thick, inflated, round-tipped ray in T. colisae, while in T. matsu it is thin and sharp tipped; 3-the posterior blade margin forms a triangular curve in T. matsu, while in T. colisae, it is growing and shallow. These three main characteristics of the species based the differentiation of trichodinid species found in the Brazilian fish of this research, coinciding with T. colisae Asmat and Sultana (2005).

Trichodina colisae was initially reported on gills of colisa Polyacanthus fasciatus (synonym Trichogaster fasciatus), an ornamental fish from Bangladesh. This is the second record of this species of trichodinid in the world and the first one in Brazil. Pacu ( $P$. mesopotamicus) and hybrid patinga ( $P$. mesopotamicus $\times$ $P$. brachypomus) are new records of hosts for this parasite.

\section{Taxonomic Summary}

- Host: Colisa (Polyacanthus fasciatus) (synonym Trichogaster fasciatus);

- Location: Bangladesh;

- New hosts: Pacu (Piaractus mesopotamicus) and hybrid patinga ( $P$. mesopotamicus $\times P$. brachypomus);

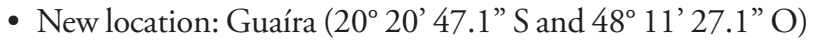
and Jaboticabal (22 $14^{\prime} 22.7^{\prime \prime} \mathrm{S}$ and $\left.48^{\circ} 17^{\prime} 33.4^{\prime \prime} \mathrm{O}\right)$, São Paulo, Southeast of Brazil; Dourados (22 $19^{\prime} 42.7^{\prime \prime} \mathrm{S}$ and $54^{\circ} 43^{\prime}$ 55.2” O), Mato Grosso do Sul, Central Brazil.

- Site of infestation: Skin, fins and gill.

\section{References}

Arthur JR, Lom J. Trichodinid protozoa (Ciliophora: Peritrichida) from freshwater fishes of Rybinsk Reservoir, USSR. J Eukaryot Microbiol 1984; 31(1): 82-91. http://dx.doi. org/10.1111/j.1550-7408.1984.tb04294.x

Asmat GSM, Sultana N. Four new species of Trichodina Ehrenberg, 1830 (Ciliophora: Trichodinidae) from Bangladeshi fish. Pakistan J Biol Sci 2005; 8(6): 895-900. http://dx.doi.org/10.3923/pjbs.2005.895.900

Basson L, Van As JG, Paperna I. Trichodinid ectoparasites of cichlid and cyprinid fishes in South Africa and Israel. Syst Parasitol 1983; 5(4): 245-257. http://dx.doi.org/10.1007/BF00009159

Basson L, Van As JG. Trichodinid ectoparasites (Ciliophora: Peritrichida) of wild and cultured freshwater fishes in Taiwan, with notes on their origin. Syst Parasitol 1994; 28(3): 197-222. http://dx.doi.org/10.1007/ BF00009518

Basson L, Van As JG. Trichodinidae and other ciliophorans (Phylum Ciliophora). In: Woo PTK. Fish Diseases and Disorders. 2nd ed. Cab International; 2006. vol. 1: Protozoan and Metazoan infections, p. 154-182.

Ghiraldelli L, Martins ML, Adamente WB, Yamashita MM. First record of Trichodina compacta Van As \& Basson, 1989 (Protozoa: Ciliophora) from cultured Nile tilapia in the State of Santa Catarina, Brazil. Int J Zool Res 2006; 2(4): 369-375. http://dx.doi.org/10.3923/ijzr.2006.369.375

Hossain MD, Hossain MK, Rahman MH, Akter K, Khanom DA. Prevalence of ectoparasites of carp fingerlings at Santaher, Bogra. Univ J Zool Rajshahi Univ 2008; 27: 17-19.

Khan RA. Disease outbreaks and mass mortality in cultured Atlantic cod, Gadus morhua L., associated with Trichodina murmanica (Ciliophora). J Fish Dis 2004; 27(3): 181-184. PMid:15009245. http://dx.doi. org/10.1111/j.1365-2761.2004.00525.x

Klein BM. The dry silver method and its proper use. J Eukaryot Microbiol 1958; 5(2): 99-103. http://dx.doi. org/10.1111/j.1550-7408.1958.tb02535.x

Lom J. A contribution to the systematics and morphology of endoparasitic trichodinids from amphibians, with a proposal of uniform specific characteristics. J Protozool 1958; 5(4): 251-263.

Lom J. Observations on Trichodinid ciliates from freshwater fishes. Arch Protistenkund 1970; 112: 153-177.

Martins ML, Ghiraldelli L. Trichodina magna Van As \& Basson, 1989 (Ciliophora: Peritrichia) from cultured Nile tilapia in the State of Santa Catarina, Brazil. Braz J Biol 2008; 68(1): 169-172. PMid:18470393. http://dx.doi.org/10.1590/S1519-69842008000100024

Martins ML, Marchiori NC, Nunes G, Rodrigues MP. First record of Trichodina heterodentata (Ciliophora: Trichodinidae) from channel catfish, Ictalurus punctatus cultivated in Brazil. Braz J Biol 2010; 70(3): 637-644. PMid:20730352. http://dx.doi.org/10.1590/ S1519-69842010000300022

Pádua SB, Martins ML, Carraschi SP, Cruz C, Ishikawa MM. Trichodina heterodentata (Ciliophora: Trichodinidae): a new parasite for Piaractus mesopotamicus (Pisces: Characidae). Zootaxa 2012; 3422: 62-68.

Pinto E, Garcia AM, Figueiredo HCP, Rodrigues MP, Martins ML. Primeiro relato de Tripartiella sp. (Ciliophora: Peritrichia) em Pseudoplatystoma corruscans (Osteichthyes: Pimelodidae) cultivado no 
Estado de Mato Grosso do Sul, Brasil, com descrição de nova espécie. $B$ Inst Pesca 2009; 35(1): 91-97.

Shwani AAA, Abdullah SMA, Asmat G. Two New Species of Trichodina Ehrenberg, 1830 (Ciliophora: Trichodinidae) from Silurus triostigus in Iraq. Eur J Sci Res 2010 40(4): 598-604.

Tang F, Zhao Y, Tao Y. Trichodinids (Ciliophora: Peritrichida) parasitic on gills of freshwater fishes, Carassius auratus and Aristichthys nobilis from China, with the description of Trichodina subtilihamata sp. nov. Zootaxa 2007; 1582: 39-48.
Van As JG, Basson L. A further contribution to the taxonomy of the Trichodinidae (Ciliophora: Peritrichia) and a review of the taxonomic status of some fish ectoparasitic trichodinids. Syst Parasitol 1989; 14(3): 157-179. http://dx.doi.org/10.1007/ BF02187051

Van As JG, Basson L. Trichodinid ectoparasites (Ciliophora: Peritrichida) of freshwater fishes of the Zambesi River System, with a reappraisal of host specificity. Syst Parasitol 1992; 22(2): 81-109. http://dx.doi. org/10.1007/BF00009603 